\title{
THE GENETIC EFFECTS OF ELEVATED TEMPERATURE IN THE YEAST, SACCHAROMYCES CEREVISIAE
}

\author{
W. E. EVANS and JAMES M. PARRY \\ Department of Genetics, University College of Swansea, Swansea SA2 8PP
}

Received 23.iv.75

\section{SumMary}

\begin{abstract}
The growth of yeast cultures at supra-optimal temperatures up to $39^{\circ} \mathrm{C}$ and exposure in non-nutrient solution up to $52^{\circ} \mathrm{C}$ has been examined for the induction of genetic change. Both sets of conditions lead to the induction of mutation to antibiotic resistance, mitotic gene conversion, crossing-over and mitotic chromosomal non-disjunction.
\end{abstract}

\section{INTRODUGTION}

THE exposure of living cells to elevated temperatures has been shown to result in several types of DNA damage including depurination, deamination of cytosine, destruction of deoxyribose residues, hydrolytic cleavage of pyrimidine glycosyl bonds (Lindahl and Nyberg, 1972), DNA strand breaks (Bridges et al., 1969; Woodcock and Grigg, 1972; Gomez and Sinskey 1973; Evans, 1974) and DNA degradation (Evans, 1974). Furthermore X-ray sensitive mutants of bacteria and yeast show increased sensitivity to heat treatment, suggesting that elevated temperatures produce some types of DNA damage similar to that produced by ionising radiations (Bridges et al., 1969; Evans and Parry, 1972).

Since elevated temperatures induce DNA damage, they may also induce genetic changes such as mutation and recombination. Several investigators have demonstrated that elevated temperatures result in increases in mutation rate. This work has been reviewed by Lindegren (1972). Of the 12 investigations into the effect of elevated temperature upon mutation rate in prokaryotes described by Lindegren all but one showed an increased mutation rate with elevated temperature. Of the six investigations using fungi cited by Lindegren, five showed increased mutation rate with increasing temperature.

In the yeast, Saccharomyces cerevisiae, Sherman (1957) has shown that elevated temperatures induce cytoplasmic petite mutants with high efficiency. Schenberg-Frasino and Moustacchi (1972) demonstrated that the induction of petites by heating at $52^{\circ} \mathrm{C}$ varied as a function of the growth phase of the cell culture, maximum induction of petites occurring in early log phase cultures. They also demonstrated that heating at $52^{\circ} \mathrm{C}$ induced forward nuclear mutations from canavanine sensitivity to canavanine resistance, however they failed to demonstrate the induction of reverse mutation from auxotrophy to prototrophy at a histidine locus.

The exposure of diploid cultures of yeast to physical and chemical mutagens results in the induction of mitotic recombination both within 
(intra-) and between (inter-) genes (Roman, 1958; James and Lee-Whiting, 1955; Parry and Cox, 1965; Yorst et al., 1967; Zimmermann and Schwailer, 1967; Parry, 1969).

The intragenic event occurs by gene converison, a process characterised by its failure to yield reciprocal products during recombination and may be scored by the formation of prototrophic revertants in auxotrophic heteroallelic yeast cultures. Intergenic recombination or crossing-over yields reciprocal products of genes and may be detected by the formation of recessive homozygous colonies in a heterozygous culture.

During mitotic cell division the failure of a pair of chromatids to separate may lead to both passing to the same pole. This process of non-disjunction may result, in a diploid cell, in the production of $2 n-1$ monosomic colonies which are distinguishable from the parental strain in suitably marked fungal cultures (Fincham and Day, 1965).

In this paper we have extended the observations upon the genetic effects of elevated temperatures to include mutation, mitotic crossing-over and gene conversion and mitotic chromosome non-disjunction. Our results demonstrate that elevated temperatures increase the frequency of all these events indicating the generality of temperature induced genetic change in eukaryotic cells.

\section{Materials AND methods}

(i) Media

The complete medium (YG) was a yeast extract, peptone medium with 4 per cent (w/v) glucose, $p \mathrm{H} 6.7$ and solidified with Lab-M Agar No. 1 (Cox and Bevan, 1962). The minimal medium (YNB) was Difco Yeast Nitrogen Base W/O amino acids, solidified with Difco Noble's Agar and supplemented with growth factors as necessary. Where required cycloheximide (KochLight Ltd.) was added to YG medium to give a final concentration of 2 p.p.m.

\section{(ii) Strains and detection of genetic change}

Mutation from $C Y H^{s}$ to $c y h^{r}$ was detected in the haploid strain: 197/2d$\alpha$ ade $_{2} \mathrm{CrH}^{\mathrm{s}}$.

Mitotic crossing-over was detected in the following diploid strains:

(a) $2 \mathrm{NJ}-a / \alpha$, ade $/ A D E$. This prototrophic strain produces white colonies on YG medium. Mitotic crossing-over produces red whole and half-red sectored recessive homozygous colonies.

(b) $\mathrm{D}_{5}-a / \alpha$, ade $e_{2-40} / a d e_{2-119}$ supplied by $\mathrm{Dr} \mathrm{F}$. Zimmermann. This culture carries two phenotypically distinguishable alleles $a d e_{2-40}$ and $a d e_{2-119}$ which produce red and pink colonies respectively and complement in heteroallelic diploids to produce white, adenine independent colonies. In $\mathrm{D}_{5}$ mitotic crossing-over results in the production of red/pink twin-spotted colonies which represent the reciprocal products of the crossing-over event. Zimmermann (1973) has demonstrated the production of twin-spotted colonies after gamma rays and ethyl methane sulphonate treatment and we have produced such colonies after UV and nitrous acid treatment.

(c) $\mathrm{JD}_{1}(21 / 8 \mathrm{a} \times 357 / \mathrm{ac})-a / \alpha, a d e_{2} / A D E, \operatorname{ser}_{1} / S E R, h i s_{8} / H I S, h i_{4 c} / h i_{4 A B C}$, $t r p_{5-u 9} / t r p_{5-u 6}$ supplied by Dr Elizabeth Hunnable. This heteroallelic diploid culture requires histidine and tryptophan for growth on YNB. 
Gene conversion results in the production of histidine and tryptophan independent colonies. The details of this strain have been described in Hunnable and Cox (1971). The subculture used in these experiments was selected for its inability to undergo sporulation.

(d) $\mathrm{D}_{6}-a / \alpha$ ade $2 / a d e_{2}$, ade ${ }_{1}$ leu trp cyhr/ADE LEU TRP $C Y H^{s}$ supplied by Dr F. Zimmermann. ade $e_{1}$ leu, trp and $c y c^{r}$ are linked genes on chromosome VII. The strain is red in colour and sensitive to cycloheximide. Mitotic non-disjunction of chromosome $\mathrm{V}$ may result in a $2 n-1$ cell which is cycloheximide resistant and coloured white (adenine- 3 mutation blocks the synthesis of the red pigment found in adenine-2 strains). Mitotic nondisjunction of chromosome VII can therefore be detected by counting the frequency of white cycloheximide resistant colonies which grow on YG medium containing 2 p.p.m. cycloheximide. After heat treatment cells of $\mathrm{D}_{6}$ were incubated for three divisions in liquid $\mathrm{YC}$ medium before plating.

\section{(iii) Heat treatment}

Heat treatment at $52^{\circ} \mathrm{C}$ was performed by exposing end of log phase yeast cells at a concentration of $10^{7}$ cells $/ \mathrm{ml}$ in saline, in a shaking waterbath for periods of up to 2 hours.

Storage experiments were performed in saline with the cells held at the appropriate temperature in an incubator for up to 30 days.

Growth experiments were performed by inoculating $10^{6} \mathrm{cells} / \mathrm{ml}$ into liquid YC medium and incubating for 24 hours with aeration in a waterbath.

\section{(iv) Incubation and scoring}

Treated cells were incubated on agar plates at $28^{\circ} \mathrm{C}$ in the dark. All the results were based upon counts of 5 to 10 plates. Cultures were diluted appropriately in order to give at least 100 colonies/plate upon YG and the various selective media.

Cell survival was scored on YC plates after 4 days' growth and the frequency of mitotic gene conversion was scored on YNB supplemented with histidine to detect tryptophan prototrophs and tryptophan to detect histidine prototrophs. Mitotic crossing-over was measured after 6 days by scoring whole red and half sectored red and white colonies on YC medium in the case of strain $2 \mathrm{NJ}$ and pink and red sectored colonies in the case of strain $\mathrm{D}_{5}$. Mutation to cycloheximide resistance and mitotic non-disjunction was measured after 8 days by scoring the frequency of all colonies and white colonies only on YC medium plus cycloheximide in the case of mutation and non-disjunction respectively.

\section{Results}

\section{(i) Induction of forward mutation}

Figure 1 demonstrates the effect of heat treatment at $52^{\circ} \mathrm{C}$ on cell viability and the frequency of forward mutation from cycloheximide sensitivity to cycloheximide resistance in strain 197/2d. The results demonstrate that heat treatment of up to 2 hours duration results in a reduction in cell viability together with an increase in mutation to cycloheximide resistance. Mutant frequency increases from $33 / 10^{7}$ survivors to $110 / 10^{7}$ survivors as the viability is decreased from 100 to 50 per cent survival. Absolute increases in 
the number of mutant colonies are found only after heat exposures greater than 15 minutes.

In order to confirm the induced nature of the cycloheximide resistant cells, samples derived from 10 independent spontaneous mutants were exposed to heat treatment. The effects upon cell viability of cycloheximide resistant cells after heat treatment at $52^{\circ} \mathrm{C}$ of a typical experiment are also shown in fig. 1. During the course of three separate experiments we were

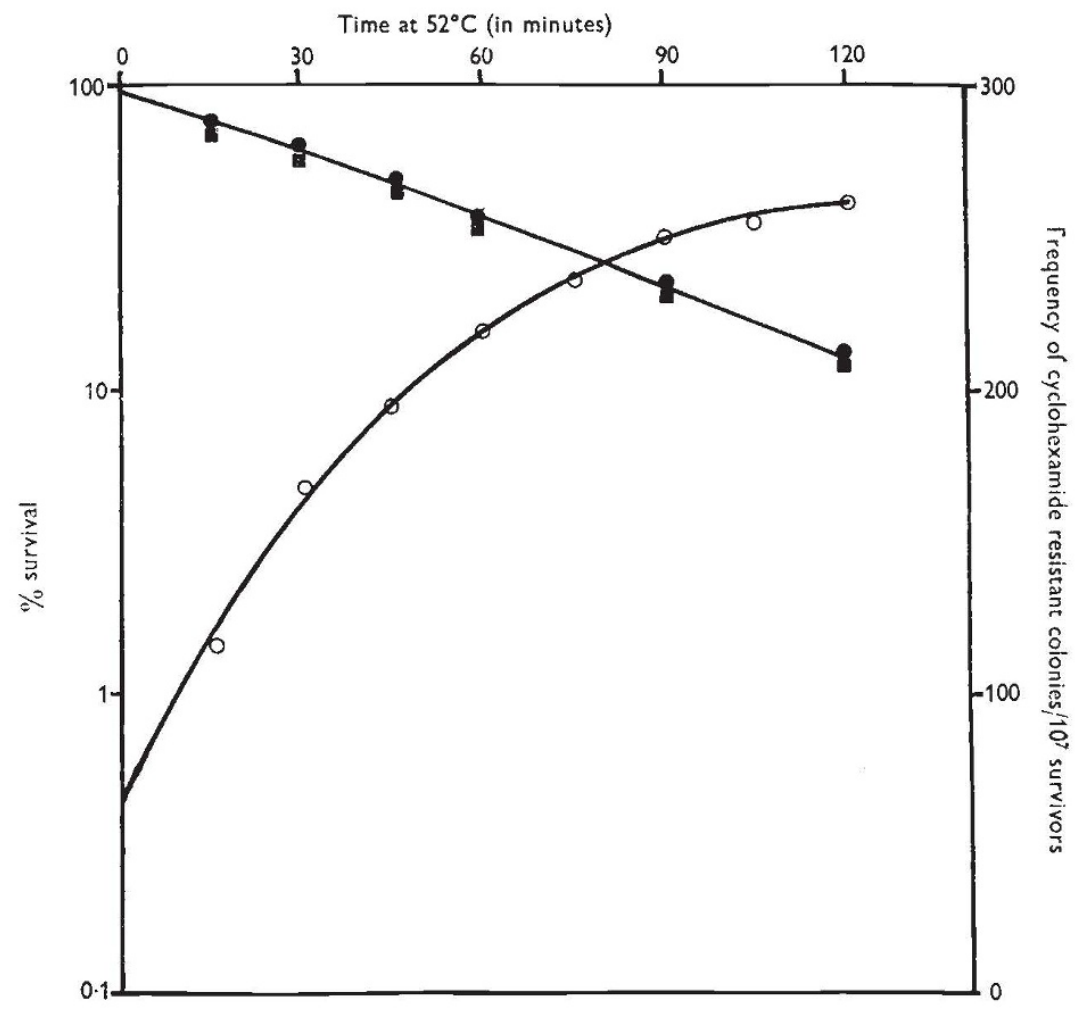

FIG. 1.-The effects of heat treatment at $52^{\circ} \mathrm{C}$ upon the mutation to cycloheximide resistance and cell viability in the haploid yeast strain 197/2d. Cell viability of cycloheximide sensitive culture; $E$, cell viability of cycloheximide resistant culture; $O$, frequency of induction of cycloheximide resistant colonies.

unable to detect any differences in the heat sensitivities of cycloheximide resistant and sensitive cells.

As shown in fig. 2 storage of cells of $197 / 2 \mathrm{~d}$ in saline at $37^{\circ} \mathrm{C}$ for up to 30 days lead to a decrease in cell viability to 10 per cent survival together with an increase in the frequency of cycloheximide resistant mutants. Storage at $28^{\circ} \mathrm{C}$ leads to only a small reduction in cell viability and increase in the frequency of cycloheximide resistant mutants. At $4^{\circ} \mathrm{C}$ no changes in cell viability are detectable.

\section{(ii) Induction of mitotic crossing-over}

The effects of heat treatment at $52^{\circ} \mathrm{C}$ for periods of up to 7 hours upon cell viability and mitotic crossing-over at the adenine- 2 locus in strain $2 \mathrm{NJ}$ are 


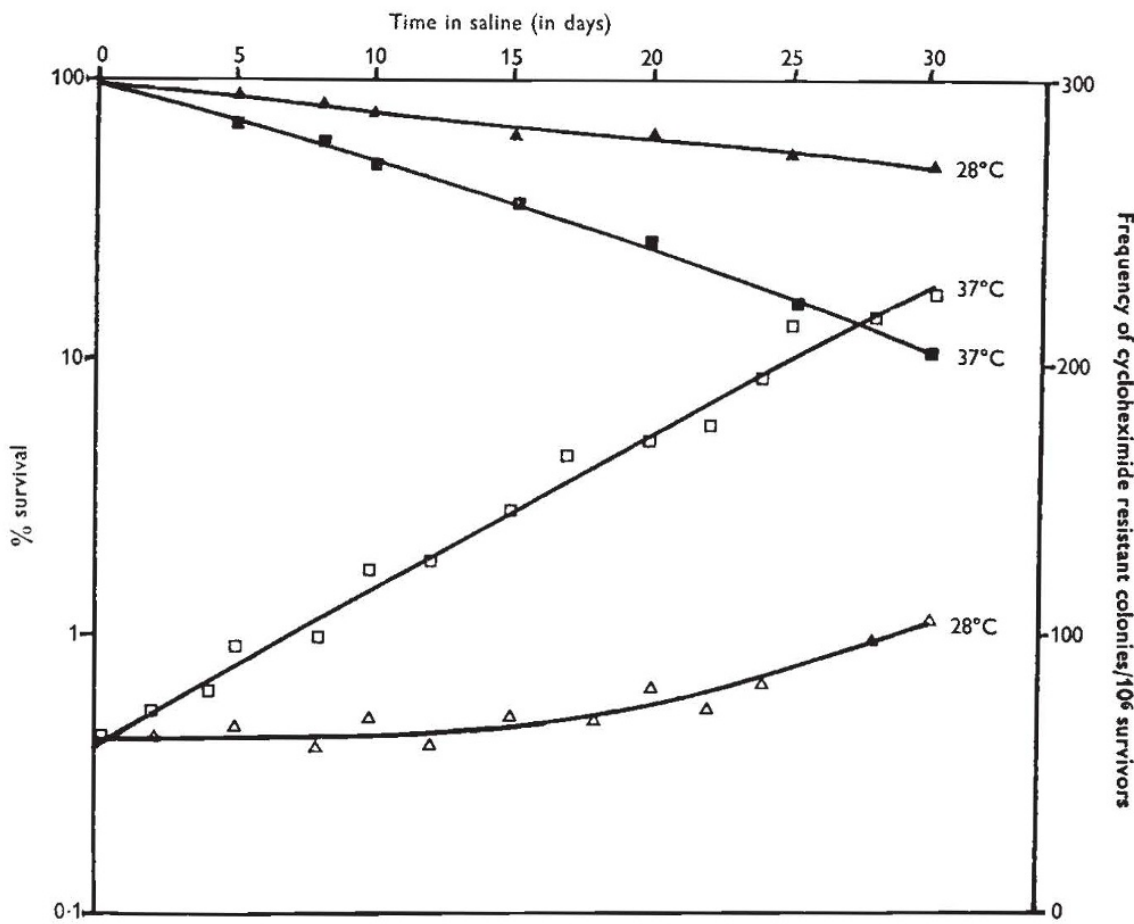

Frg. 2.-The effects of incubation in saline at $28^{\circ} \mathrm{C}$ and $37^{\circ} \mathrm{C}$ upon cell viability and mutation to cycloheximide resistance in haploid culture $197 / 2 \mathrm{~d}$. $\Delta$, cell viability at $28^{\circ} \mathrm{C} ; \boldsymbol{\Pi}$, cell viability at $37^{\circ} \mathrm{C} ; \triangle$, frequency of cycloheximide resistant colonies at $28^{\circ} \mathrm{C} ; \square$, frequency of cycloheximide resistant colonies at $37^{\circ} \mathrm{C}$.

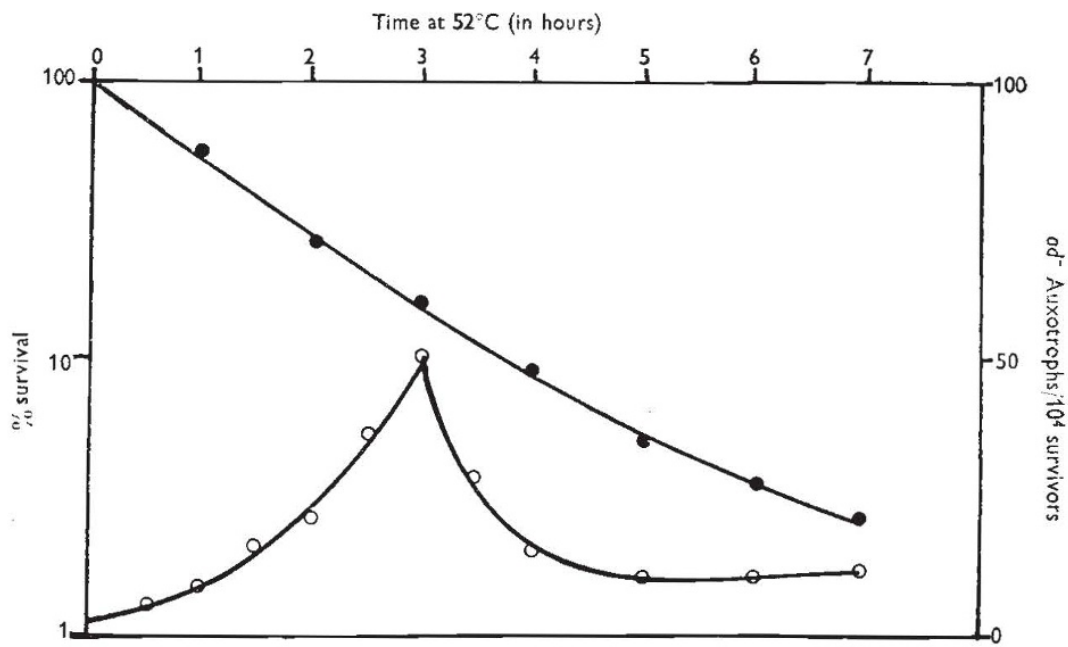

Frg. 3.-The effects of heat at $52^{\circ} \mathrm{C}$ upon cell viability and the induction of recessive homozygous adenine requiring cells produced by mitotic crossing-over in the diploid yeast strain $2 \mathrm{NJ}$.

, Cell viability; $O$, frequency of adenine-requiring colonies. 
shown in fig. 3. The frequency of recessive homozygosis is increased from a spontaneous level of 0.02 per cent to a maximum of 0.5 per cent after 3 hours. Longer incubation times at $52^{\circ} \mathrm{C}$ result in decreases in recessive homozygosis (an effect also observed with treatment with UV, gamma rays, ethyl methane sulphonate and nitrous acid; Davies et al., 1975). The increase in recessive homozygosis is observed only at periods of heat treatment leading to cell lethality.

In order to confirm that heat induced recessive homozygosis results from mitotic crossing-over the experiment was repeated with strain $D_{5}$. In this strain both the reciprocal products of a mitotic cross-over event may be detected in the form of red and pink twin spot colonies. The effects of $52^{\circ} \mathrm{C}$ treatment on the production of phenotypically distinguishable colonies in strain $\mathrm{D}_{5}$ are shown in table 1 . The results demonstrate that heat treatment

TABLE 1

The induction of mitotic crossing-over by heat treatment at $52^{\circ} \mathrm{C}$ in diploid culture $D_{5}$

$\begin{array}{lcccccccc}\text { Treatment } & \begin{array}{c}\text { Cell } \\ \text { viability }\end{array} & \begin{array}{c}\text { pink/ } \\ \text { red }\end{array} & \text { pink } & \text { red } & \begin{array}{c}\text { pink/ } \\ \text { white }\end{array} & \begin{array}{c}\text { red/ } \\ \text { white }\end{array} & \begin{array}{c}\text { Total } \\ \text { colonies } \\ \text { analysed }\end{array} & \begin{array}{c}\text { Percentage } \\ \text { reciprocal } \\ \text { recombinants }\end{array} \\ \text { Control } & 100 \% & 1 & 0 & 2 & 1 & 0 & 4972 & 0.0201 \\ 120 \text { min. at } 52^{\circ} \mathrm{C} & 57 \cdot 4 & 4 & 6 & 4 & 7 & 5 & 976 & 0.40 \\ 180 \text { min. at } 52^{\circ} \mathrm{C} & 20 \cdot 1 & 6 & 15 & 40 & 13 & 16 & 578 & 1.03 \\ 210 \text { min. at } 52^{\circ} \mathrm{C} & 6 \cdot 74 & 9 & 59 & 142 & 39 & 22 & 972 & 0.92 \\ 240 \text { min. at } 52^{\circ} \mathrm{C} & 1.4 & 54 & 36 & 402 & 128 & 163 & 1982 & 2 \cdot 72\end{array}$

leads to the production of colony colours including red/pink twin spot colonies. Thus we may conclude that $52^{\circ} \mathrm{C}$ heat treatment leads to the induction of mitotic crossing-over between the $a d e--_{2}$ gene and the centromere of chromosome XV.

At the lower temperature of $37^{\circ} \mathrm{C}$ storage of strain $2 \mathrm{NJ}$ in saline for up to 30 days also leads to an increase in the frequency of recessive homozygosis up to a frequency of 0.4 per cent of the surviving cells (fig. 4). No such increase in the frequency of recessive homozygosis is detectable when $2 \mathrm{NJ}$ is held at $28^{\circ} \mathrm{C}$ for up to 30 days.

The induction of recessive homozygosis in strain $2 \mathrm{NJ}$ was measured in growing cultures at a range of temperatures up to $39^{\circ} \mathrm{C}$. The results of these experiments are shown in fig. 5, for growth periods of up to 24 hours, during which time cell number increases from $10^{6} / \mathrm{ml}$ to $10^{8} / \mathrm{ml}$. At $28^{\circ} \mathrm{G}$ no increase in the frequency of recessive homozygosis is detectable. At the higher temperatures of $37^{\circ}, 38^{\circ}$ and $39^{\circ} \mathrm{C}$ the frequency of recessive homozygosis increases to a maximum of 0.6 per cent at $38^{\circ} \mathrm{C}$. No growth of $2 \mathrm{NJ}$ could be detected at temperatures above $39^{\circ} \mathrm{C}$.

\section{(iii) Induction of mitotic gene conversion}

Figure 6 demonstrates the inactivation of $\mathrm{JD}_{1}$ at $52^{\circ} \mathrm{C}$ together with the increase in prototrophic convertants at the tryptophan-5 and histidine- 4 loci. The results indicate that heat treatment at $52^{\circ} \mathrm{C}$ leads to an increase in prototrophic convertants per surviving cell at both loci. Mitotic gene 


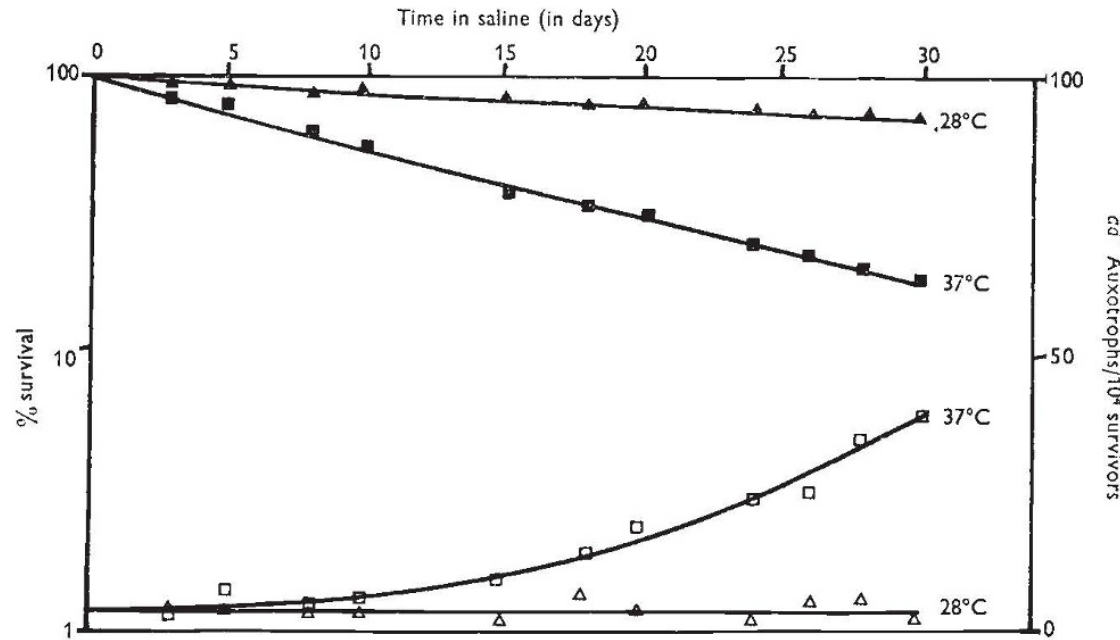

FIG. 4.-The effects of incubation in saline at $28^{\circ} \mathrm{C}$ and $37^{\circ} \mathrm{C}$ upon cell viability and the induction of adenine requiring cells produced by mitotic crossing-over in the diploid culture $2 \mathrm{NJ}$. $\Delta$, Gell viability at $28^{\circ} \mathrm{C} ; \boldsymbol{D}$, cell viability at $37^{\circ} \mathrm{C} ; \triangle$, recessive homozygous colonies at $28^{\circ} \mathrm{C} ; \square$, recessive homozygous colonies at $37^{\circ} \mathrm{C}$.

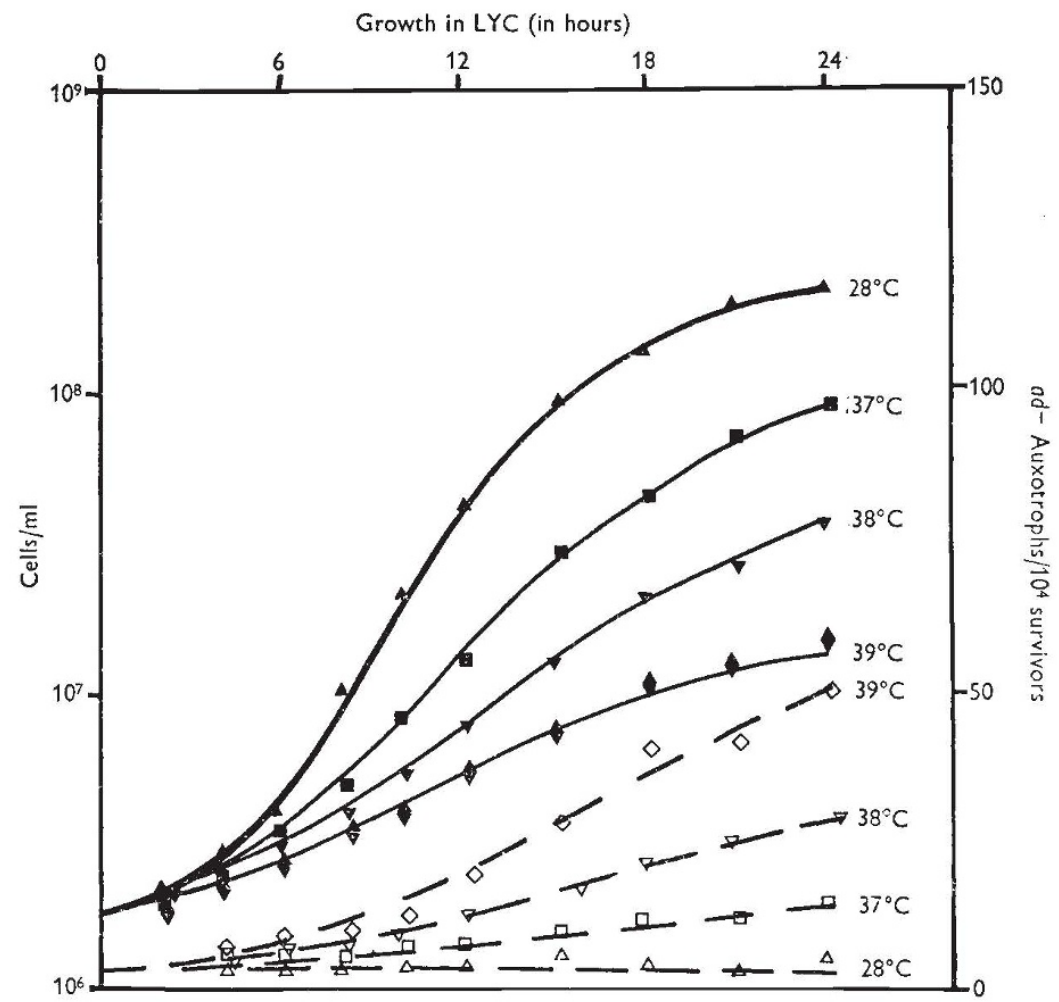

FIG. 5.-The effects of growth at temperatures from $28^{\circ} \mathrm{C}$ to $39^{\circ} \mathrm{C}$ upon the induction of adenine requiring cells produced by mitotic crossing-over in the diploid culture $2 \mathrm{NJ}$. $\Delta$, Increase in cell numbers at $28^{\circ} \mathrm{C} ; \boldsymbol{\square}$, increase in cell numbers at $37^{\circ} \mathrm{C} ; \boldsymbol{\nabla}$, increase in cell numbers at $38^{\circ} \mathrm{C} ; \diamond$, increases in cell numbers at $39^{\circ} \mathrm{C} ; \triangle$, recessive homozygosis at $28^{\circ} \mathrm{C} ; \square$, recessive homozygosis at $37^{\circ} \mathrm{C} ; \nabla$, recessive homozygosis at $38^{\circ} \mathrm{C} ; \diamond$, recessive homozygosis at $39^{\circ} \mathrm{C}$. 
conversion is increased to a greater extent at the tryptophan-5 locus compared with the histidine-4 locus. A similar difference in the extent of conversion induction at the two loci is shown by chemical mutagen treatment (Davies, Evans and Parry, 1975). At periods of $52^{\circ} \mathrm{C}$ treatment above 60 minutes,

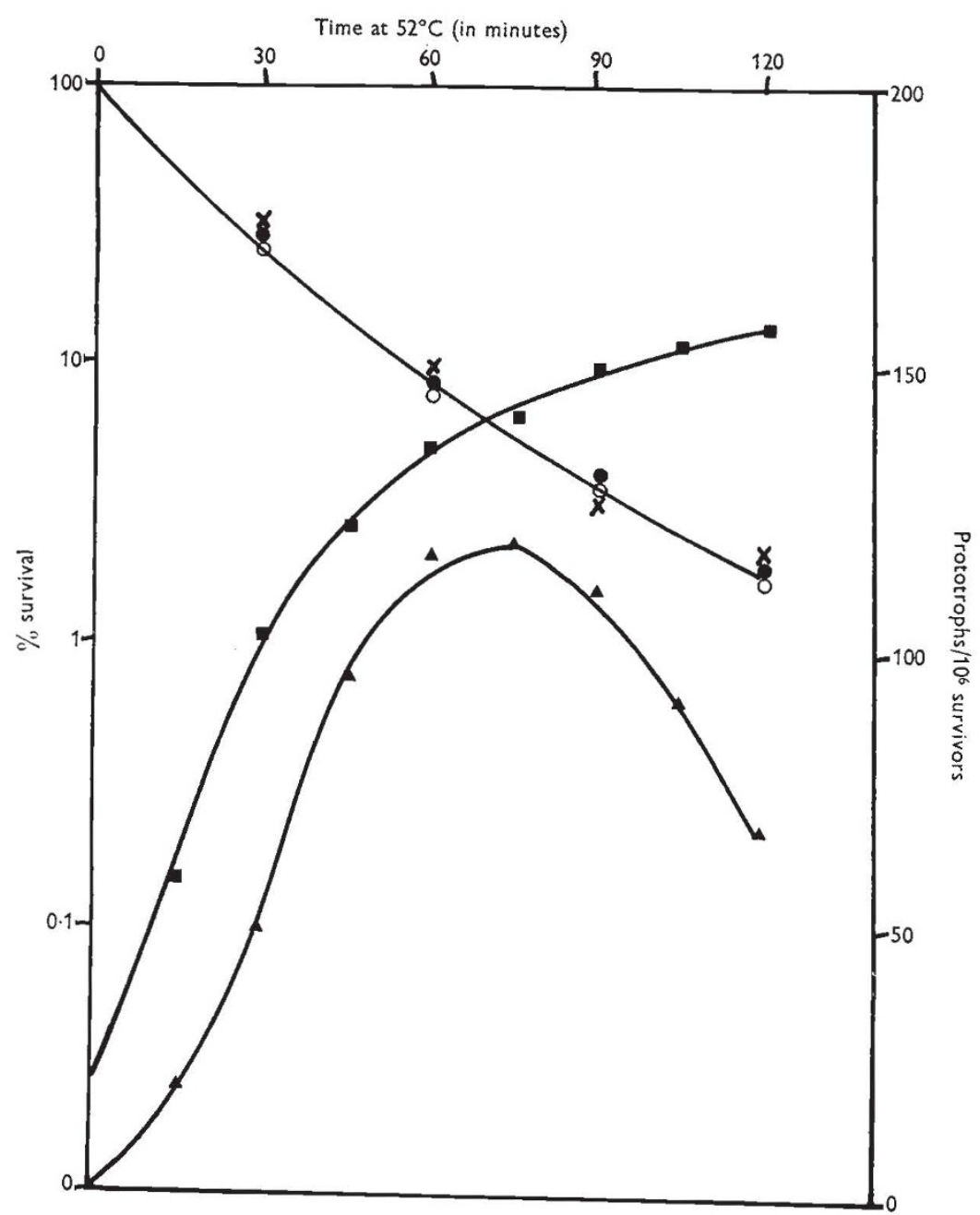

Fig. 6.-The effects of heat treatment at $52^{\circ} \mathrm{C}$ upon cell viability and the production of prototrophs by mitotic gene conversion in the diploid culture $\mathrm{JD}_{1}$. $\quad$, Cell viability of his ${ }^{-}$trp ${ }^{-}$cells of $\mathrm{JD}_{1}$ at $52^{\circ} \mathrm{C} ; \times$, cell viability of $h i s^{+} t r p^{-}$cells of $\mathrm{JD}_{1}$ as $52^{\circ} \mathrm{C}$; O, cell viability of $h$ is $^{-}{ }^{-} r p^{+}$cells of $\mathrm{JD}_{1}$ at $52^{\circ} \mathrm{C} ; \boldsymbol{\square}$, induction of $t r p \mathrm{~F}$ cells at $52^{\circ} \mathrm{C} ; \boldsymbol{\Delta}$, induction of hisF cells at $52^{\circ} \mathrm{C}$.

the frequency of histidine-4 prototrophs falls with increase in cell lethality. Absolute increases in the frequency of prototrophs per plate are not found in our experiments. Thus in order to check for selective effects the heat sensitivity of samples derived from 10 independent spontaneous histidine and 10 independent spontaneous tryptophan prototrophs were determined and the results of a typical experiment are shown in fig. 6 . In no case could any 
difference in the heat sensitivity of prototrophic and auxotrophic cultures of $\mathrm{JD}_{1}$ be detected.

Storage of strain $\mathrm{JD}_{1}$ at $37^{\circ} \mathrm{C}$ in saline for up to 15 days also induced mitotic gene conversion at both the histidine-4 and tryptophan-5 loci (fig. 7). The dose response curves obtained are very similar to those obtained after treatment at $52^{\circ} \mathrm{C}$. Again absolute increases in plate counts were not found. Small increases in gene conversion at both the histidine- 4 and

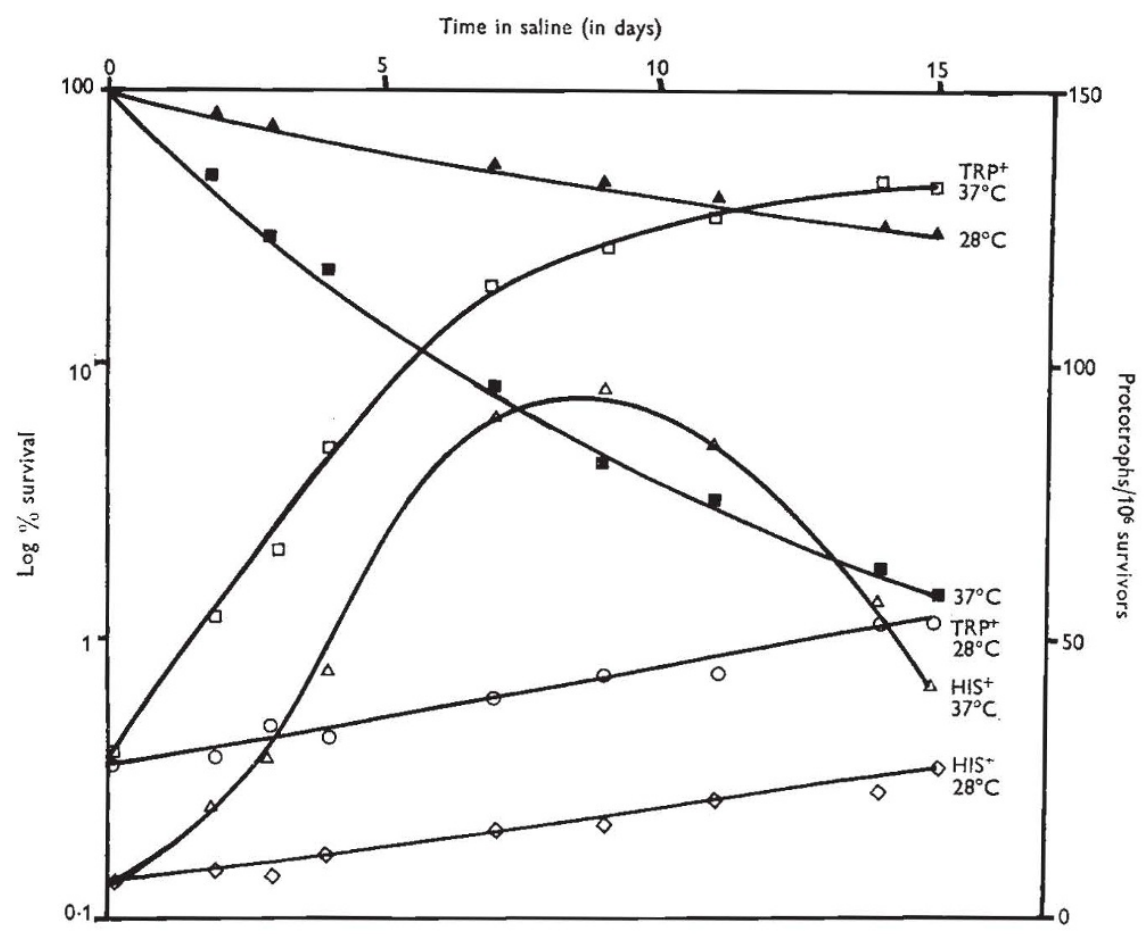

Fig. 7.-The effects of incubation in saline at $28^{\circ} \mathrm{C}$ and $37^{\circ} \mathrm{C}$ upon cell viability and the production of prototrophs by mitotic gene conversion in the diploid culture $\mathrm{JD}_{1}$. $\Delta$, Cell viability at $28^{\circ} \mathrm{C} ; \mathbf{E}$, cell viability at $37^{\circ} \mathrm{C} ; 0$, induction of $t r p^{+}$cells at $28^{\circ} \mathrm{C} ; \diamond$, induction of his $^{+}$cells at $28^{\circ} \mathrm{C} ; \square$, induction of $\operatorname{trp}^{+}$cells at $37^{\circ} \mathrm{C} ; \triangle$, induction of $h i s^{+}$cells at $37^{\circ} \mathrm{C}$.

tryptophan-5 loci are also obtained after storing at $28^{\circ} \mathrm{C}$. Neither cell viability nor the frequency of gene conversion at either loci is affected after storing the cells of $\mathrm{JD}_{1}$ for 15 days at $4^{\circ} \mathrm{C}$.

Figure 8 demonstrates the effects of growing the cells of $\mathrm{JD}_{1}$ in liquid growth medium at $28^{\circ} \mathrm{C}$ and $37^{\circ} \mathrm{C}$ upon the frequency of mitotic gene conversion at the histidine- 4 and tryptophan-5 loci. Increases in gene conversion at both loci are produced when cells of $\mathrm{JD}_{1}$ are grown at $37^{\circ} \mathrm{G}$. No such increase in gene conversion is observable when cells of $\mathrm{JD}_{1}$ are grown at $28^{\circ} \mathrm{C}$.

\section{(iv) Induction of mitotic chromosome non-disjunction}

Figure 9 demonstrates the inactivation of strain $\mathrm{D}_{1}$ and the frequency of white, cycloheximide resistant cells produced by mitotic non-disjunction. 
The frequency of white, cycloheximide resistant cells increases after test treatment from 1 per $10^{5}$ cells to 30 per $10^{5}$ cells after heating at $52^{\circ} \mathrm{C}$ for 3 hours. The observation of white, cycloheximide resistant cells is dependent upon cell division in non-selective medium after heat treatment. No increase in the frequency of cells produced by mitotic non-disjunction are detectable if heat treated cells are plated directly upon selective medium.

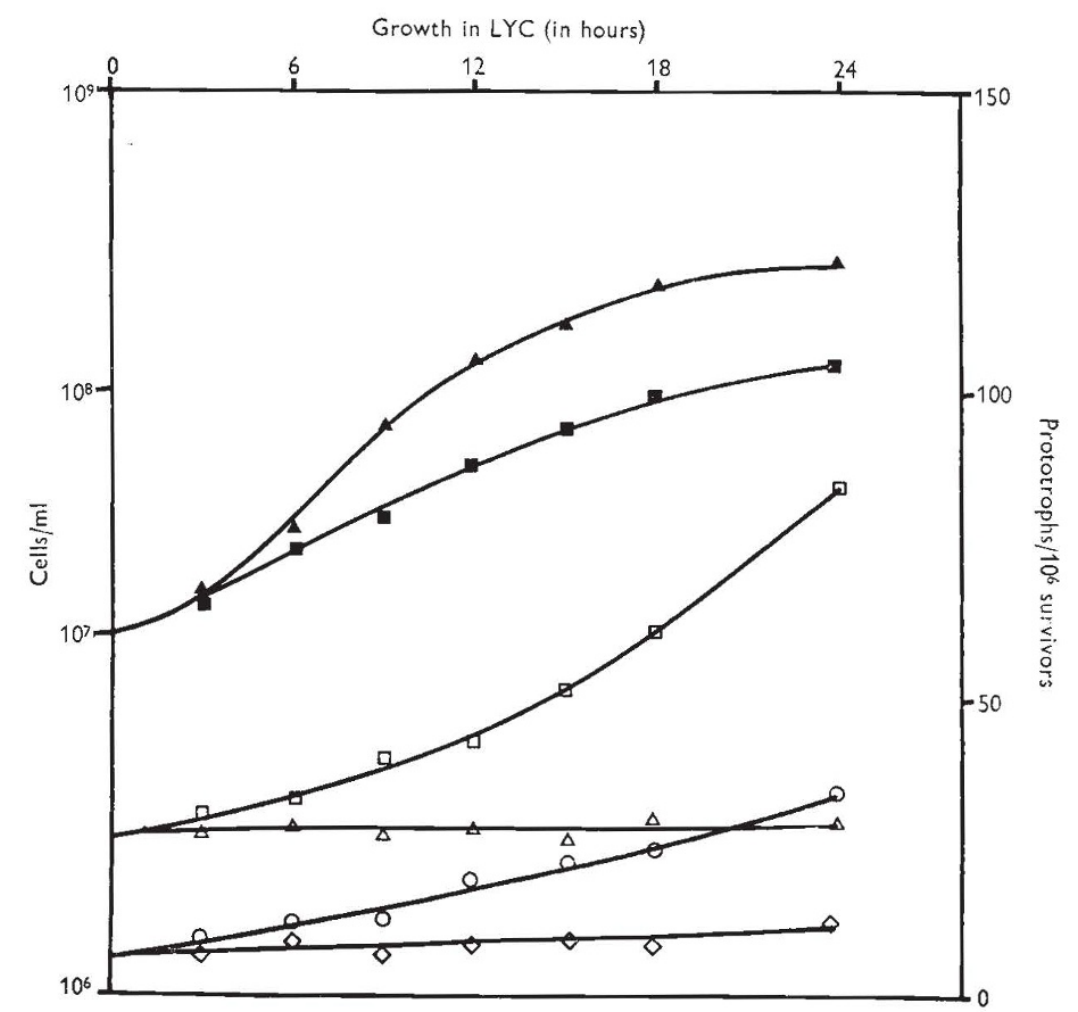

Fig. 8.-The effects of growth at $28^{\circ} \mathrm{C}$ and $37^{\circ} \mathrm{C}$ upon the production of prototrophs by mitotic gene conversion in the diploid culture $\mathrm{JD}_{1} . \Delta$, Increase in cell numbers at $28^{\circ} \mathrm{C} ; 0$, increase in cell numbers at $37^{\circ} \mathrm{C} ; \triangle$, induction of $t r p^{+}$cells at $28^{\circ} \mathrm{C} ; \diamond$, induction of is $^{+}$cells at $28^{\circ} \mathrm{C} ; \square$, induction of trp $^{+}$cells at $37^{\circ} \mathrm{C} ; O$, induction of $h i s^{+}$ cells at $37^{\circ} \mathrm{C}$.

Growth of strain $\mathrm{D}_{1}$ at temperatures above $36^{\circ} \mathrm{C}$ for periods of 24 hours also produce increases in the frequency of white, cycloheximide resistant cells produced by mitotic chromosome non-disjunction, e.g. at $41^{\circ} \mathrm{C}$ the frequency of such cells increased to $22 / 10^{5}$ cells compared with a frequency of $1 / 10^{5}$ cells at $28^{\circ} \mathrm{C}$.

\section{Discussion}

The results presented demonstrate that heat treatment at $52^{\circ} \mathrm{C}$ and storage in saline at $37^{\circ} \mathrm{C}$ resulted in the induction of mutations from cycloheximide sensitivity to resistance. These results confirm the observations of Schenberg-Frascino and Moustacchi (1972) who found that $52^{\circ} \mathrm{C}$ treatment induced mutation to canavanine resistance. The results also confirm the 
observations of Drake (1966) that lesions leading to mutation accumulate during storage in non-nutrient media, i.e. in non-replicating cells, and that this accumulation is a function of temperature.

Heat treatment at $52^{\circ}$ and $37^{\circ} \mathrm{C}$ increased the frequency of mitotic crossing-over at the adenine- 2 locus. This increase was observed only at exposures producing cell death. A direct correlation between crossing-over and cell lethality has been observed after treatment of yeast cells with a wide range of physical and chemical mutagens (Davies et al., 1975). The latter

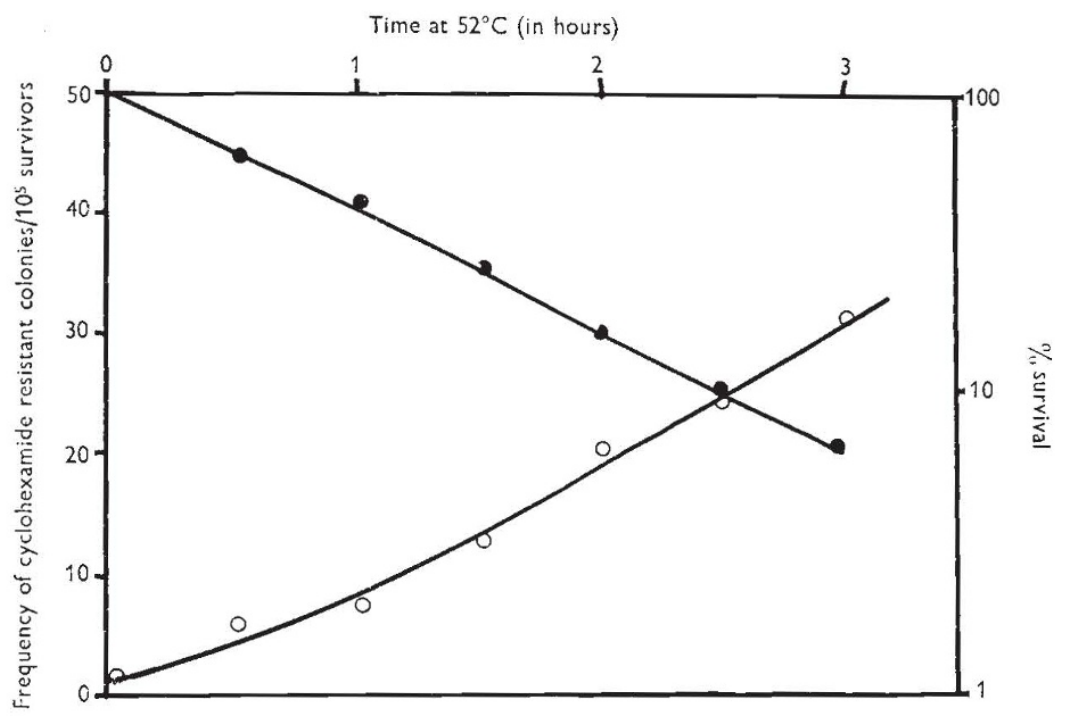

Fig. 9.-The effects of heat treatment at $52^{\circ} \mathrm{C}$ upon cell viability and the frequency of white cycloheximide resistant cells produced by mitotic non-disjunction in diploid culture $\mathrm{D}_{6}$. - Cell viability of $D_{6}$ after $52^{\circ} \mathrm{C}$ treatment; $O$, frequency of white cycloheximide resistant cells after $52^{\circ} \mathrm{C}$ treatment.

have suggested the lesions responsible for cell death are also involved in the induction of mitotic crossing-over. Furthermore, the reduction in induced recombinants at high levels of cell lethality observed after heat treatment also occurs with UV, gamma rays, ethyl methane sulphonate and nitrous acid, suggesting that failure to repair potentially lethal lesions also results in a failure to produce mitotic crossing-over. Reductions in recombination at high doses may result from an inhibition of repair activity in the treated cells.

Heat treatment at $37^{\circ}$ and $52^{\circ} \mathrm{C}$ increased the frequency of mitotic gene conversion at the tryptophan-5 and histidine- 4 loci. However absolute increases in plate counts were not found and mitotic gene conversion was only induced at exposures producing cell lethality. In this respect the induction of gene conversion by heat treatment differs from that produced by radiations and most chemical mutagens, in that the latter increases the frequency of gene conversion at exposures causing little or no cell lethality (Davies et al., 1975) indicating that heat treatment produces no recombinogenic lesions that are not also potentially lethal.

Elevated temperatures were also shown to increase the frequency of 
monosomic $(2 n-1)$ cells for chromosome VII, presumably produced by mitotic chromosome non-disjunction.

The frequencies of mitotic gene conversion, crossing-over and chromosome non-disjunction were also increased by growth in nutrient media at temperatures above the optimum. Therefore it appears that cells growing at supra-optimal temperatures are particularly prone to genetic change. These effects may be due to:

1. Inefficient repair of heat induced DNA damage in cells growing at the temperatures.

2. Inaccuracy, during growth at high temperatures, of the enzymes responsible for DNA replication.

However, the evidence presented here showing that elevated temperature induces genetic damage suggests that the former explanation is more probable. Freese (1963) has suggested that depurination is partially responsible for the mutagenic effects of alkylating agents. It is therefore a possibility that heat induced mutation also results from depurination. Heat induced mitotic crossing-over may result from DNA strand breakage followed by reunion between homologous chromosomes. A number of pieces of evidence (Evans, 1974; Davies et al., 1975) suggest that DNA damage in yeast may be repaired by an enzymatic process which leads to mitotic gene conversion. The induction of mitotic gene conversion by elevated temperatures may therefore be the consequence of the repair of heat induced DNA damage by such a process.

Acknowledgements.- This work was supported under contract Bl0E 119/7/2 from Euratom. One of us (W. E. E.) held a University of Wales Studentship during the course of the work. We wish to express our thanks to Mrs Margaret Bonham-Clatworthy for her skilled technical assistance.

\section{REFERENCES}

BRIDGES, B. A., ASHWOOD-SMrth, M. J., AND MUNSON, R. T. 1969. Susceptibility of mild thermal and of ionising radiation damage to the same recovery mechanisms in $E$. coli. Biochem. Biophys. Res. Comm., 35, 192-196.

Cox, B. s., ANd bevan, E. A. 1962. Aneuploidy in yeast. New Phytol., 61, 342-355.

DAVIES, P. J., EVANS, W. E., AND PARRY, J. M. 1975. Mitotic recombination induced by chemical and physical agents in the yeast Saccharomyces cerevisiae, Mut. Res., 29, 301314.

DRAKE, J. W. 1966. Spontaneous mutations accumulating in bacteriophase T4 in the complete absence of DNA replication. Proc. Natl. Acad. Sci., U.S.A., 55, 738-743.

EVANs, w. E. 1974. Studies upon the inactivation and repair of cellular damage induced by chemical and physical agents. Ph.D. thesis, University College of Swansea.

EVANS, w. E., AND PARRY, J. M. 1972. The cross sensitivity to radiations, chemical mutagens and heat treatment of X-ray sensitive mutants of yeast. Molec. gen. Genet., 118, 261-271.

fincham, J. R. s., AND DAY, P. R. 1965. Fungal Genetics, 2nd ed. Blackwell Scientific Publications, Oxford.

FREESE, E. 1963. Molecular mechanisms of mutation. In J. H. Taylor (ed.), Molecular Genetics, Part I, pp. 207-270. Johns Hopkins, Academic Press.

GOMEZ, R. F., AND sINSKEY, A. J. 1973. DNA strand breaks in treated Salmonella typhimurium $L T-2$ after exposure to nutritionally complex media. 7. Bacteriol., 115, 522-528.

HUNNABLE, E. G., AND COX, B. s. 1971. The genetic control of dark recombination in yeast. Mut. Res., 13, 297-309.

JAMES, A. P., AND LEE-WHITING, A. 1955. Radiation induced genetic segregation in vegetative cells of diploid yeast. Genetics, 40, 826-835.

LINDAHL, T., AND NYBERG, B. 1972. Rate of depurination of native DNA. Biochem., 11, 3611-3618. 
LINDEGREN, D. 1972. The temperature influence on the spontaneous mutation rate. 1. Literature review. Heredity, 70, 165-168.

PARRY, J. M., AND COX, B. s. 1965. Photoreactivation of UV induced reciprocal recombination, gene conversion and mutation to prototophy in Saccharomyces cerevisiae. 7. gen. Microbiol., 40, 235-241.

PARRY, J. M. 1969. Comparison of the effects of ultraviolet light and ethylmethane sulphonate upon the frequency of mitotic recombinations in yeast. Molec. Gen. Genet., 106, 66-72.

ROMAN, H. 1958. Sur les recombinations nonréciproques chez Saccharomyces cerevisiae et sur les problèmes poses par les phénomènes. Ann. Génét., 1,11 .

SCHENBERG-FRASCINO, A., AND MOUSTACCHI, E. 1972. Lethal and mutagenic effects of elevated temperatures in haploid yeast. I. Variation in sensitivity during the cell cycle. Molec. Gen. Genet., 115, 243-257.

SHERMAN, F. 1957. The heat in-activation and production of cytochrome deficiency in yeast. Exp. Cell Res., 11, 659-660.

WOODCOCK, E., AND GRIGG, G. w. 1972. Repair of thermally induced DNA breakage in $E$. coli. Nature, New Biology, 237, 76-79.

YORST, H. T., CHALEFF, R. S., AND FINERTY, J. P. 1967. Induction and mitotic recombination in Saccharomyces cerevisiae by ethyl methanesulphonate. Nature, 215, 660-661.

ZIMMERMANN, F. K., AND SCHWAIER, R. 1967. Induction of mitotic gene-conversion with nitrous acid, 1-methyl-3-nitro-1-nitrosoguanidine and other alkylating agents in Saccharomyces cerevisiae. Mol. Gen. Genet., 100, 63-76.

ZIMMERMANN, F. K. 1973. A yeast strain for visual screening of the reciprocal products of mitotic crossing-over. Mutation Res., 21, 83-91. 